\title{
CONTENTS OF CLINICAL HEMORHEOLOGY, VOLUME 14, NUMBER 2
}

S. Witte and J.-F. Stoltz

J.G. Jones, R.A. Adams and S.-A. Evans

M.R. Boisseau, E. Mazoyer, L. Ripoll

P. Lechner, M. Walzl and B. Walzl

F. Jung, J. Koscielny, C. Mrowietz, G. Pindur, H. Förster, W. Schimetta, H. Kiesewetter and $E$. Wenzel

E. Tozzi, M.G. Tozzi-Ciancarelli, C. Di Massimo, A. Mascioli, T. Gentile and $F$. de Matteis

A. Luquita, A. Dominighini, R. Rasia and M. Rasia

M. Mukherjee and A.P. Desai

P. Ruef, E.P. Zilow and O. Linderkamp
147

Editorial

Review Article

149 Bulk filtration through micropore membranes for analysing blood cell rheology in clinical research

Conference Communications

Proceedings of the First International and Eighth European Conference on Clinical Hemorheology, Vienna, Austria, 5-8 July 1993 - Part IV

\section{Symposium:}

171 Hemorheologically active substances, their profile and L. Drouet and clinical impact

Symposium: Plasmapheresis: HELP

181 The impact of H.E.L.P. on haemorheology in peripheral arterial disease

Free Session: Hemodilution

189 Elimination kinetics of different hyrdoxyethyl starches and effects on blood fluidity

Non-Conference Communications

Papers

203 Hemorheological parameters and body weight loss in obese children

213 Erythrocyte rheology in standarized experimental chronic renal failure

223 Evaluation of platelet aggregability by computerised probit analysis

233 Deformability of peripheral immature and mature neutrophils

(Contents Continued) 
(Continuation of Contents)

X. Wang and J.-F. Stoltz

P. Kent, G. Williams and R. C. Kester

M. Boynard, F. Ribier, R. Guillet, F. Driss, P. Perrotin, F. Gaudey, C. Pautou and B. Nalpas

H. Landgraf, D. Schulte-Huermann and A.M. Ehrly

M.V. Kulkarni and R.R. Puniyani

Wen Zong-yao, Tao Zu-lai, Ma Wei-yuan, Sun Da-gong and Li Tian-xun

G. Mchedlishvili

Submitted by Editor-in-Chief, J.-F. Stoltz
237 Characterization of pathological bloods with a new rheological relationship

245 The effect of acute hand vibration on red cell filterability

255 Assessment of red blood cell deformability in healthy adult subjects: Influence of sex, age, cigarette smoking, menstrual cycle and oral contraceptives

263 Muscle tissue oxygen pressures in healthy volunteers during acute exposure to hypoxia

271 Study of hemorheological parameters in maturity onset diabetic cases

\section{Brief Communication}

279 The influence of surface charge of RBC membrane upon RBCs orientation in a shear flow field of low viscosity

Letter to the Editors-in-Chief

Principle factors deranging blood rheological properties in microvessels

\section{Abstracts}

287 Abstracts of papers presented at the Congress of the French Society of Fundamental and Clinical Biorheology 3-4 June, 1993 San Malo, France

\section{Announcements}

299 17th World Congress of the International Union of Angiology, London (UK) 3-7 April, 1995

301 Royal College of Physicians of Edinburgh - Second International Symposium on Fibrinogen and Cardiovascular Disease, 1-2 November, 1994

302 Contents of Biorheology Volume 30, Numbers 5/6 